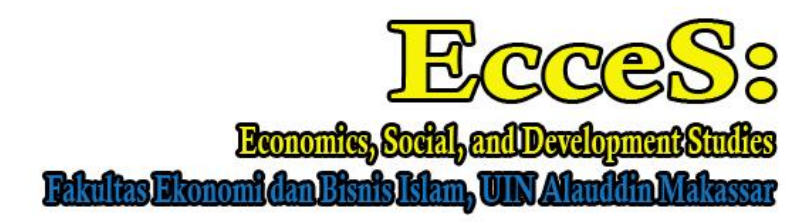

Volume 8 Number 2 Ed. December 2021: page:111-131 p-ISSN: 2407-6635 e-ISSN : 2580-5570

\title{
Economic Valuation of Lake Tempe Area Resources in Wajo Regency; A Socio-Economic and Ecological Approach
}

\section{Ecces: \\ Economics Social and Development Studies}

\author{
Darsam Belana ${ }^{1 *}$ \\ ${ }^{1}$ Hasanuddin University \\ Jl. Perintis Kemerdekaan KM. 10, Makassar 90245, Indonesia \\ E-mail : darsam.belana86@gmail.com * \\ (Article history) Received: 2021-11-29, Revised: 2021-12-22, Accepted: 2021-12-23 \\ Available online: 2021-12-24, DOI: 10.24252/ecc.v7i1.13382, \\ Stable URL: http://journal.uin-alauddin.ac.id/index.php/ecc/index
}

\section{Abstract: Economic Valuation of Lake Tempe Area Resources in Wajo Regency; A Socio-Economic and Ecological Approach}

So far, there have been no economic valuation studies to ecological studies that reveal the potential of the Tempe Lake area, so that policy makers have not been able to manage and use the Tempe Lake Area, at the most effective and efficient level, and able to distribute the benefits and costs of conservation fairly. The novelty of this research is trying to do an economic valuation, which is paralleled with an ecological study of the existence of Lake Tempe. This study aims to identify the ecological functions of Lake Tempe that give rise to various economic and non-economic benefits for the community around Lake Tempe, as well as to determine the amount of Total Economic Value (NET) of Lake Tempe. The data were analyzed by adding up the value of direct benefits, value of indirect benefits, value of choice benefits, value of existence benefits and value of inheritance benefits in the Tempe Lake area. This research data was collected through surveys and interviews with stakeholders who have a reciprocal relationship with the Tempe Lake area in Wajo Regency. The results showed that the total economic value obtained for the Tempe Lake area was Rp. $5,742,249,708,120$,- per year with the largest contribution coming from the direct benefit value of Rp. $4,571,395,793,250,-$ per year or $78.7 \%$. The implication of the research is the need for cross-sectoral joint coordination from various levels of government, to encourage the rehabilitation of forest areas around the Walennae and Bila watersheds. Dredging of Lake Tempe is urgently needed to cope with the annual flooding due to overflow of water. In addition, to increase the utilization of Lake Tempe, a more massive synergy between stakeholders is needed, to develop other untapped potential of the Lake Tempe area.

Keywords: Valuation; Resource Economics; Ecology 
Darsam Belana, Economic Valuation of Lake Tempe Area Resources in Wajo Regency; A Socio-Economic and Ecological Approach.

\section{INTRODUCTION}

Ecological damage necessitates environmental damage to the livelihoods of the surrounding community, this is a very real phenomenon in various areas, both at the rural to urban level. Faccioni et al., (2019). The problem faced by Lake Tempe is that every rain in the upstream area will cause an overflow of water from Lake Tempe which causes flooding in the area around the lake. In addition to flooding, sediment deposits from mud washed away by river currents resulted in the lake getting shallower. The total sediment that enters Lake Tempe is $1,069,099$ million m3 according to a study by JICA in 2002 and the Bappedalda of Wajo Regency that every year there is silting that ranges from $15-20 \mathrm{~cm}$ and tends to increase every year.

Table 1.1 Area, Depth, and Volume of Lakes in Indonesia in 2020

\begin{tabular}{|c|c|c|c|c|c|c|c|}
\hline Num & $\begin{array}{l}\text { Name of } \\
\text { lake }\end{array}$ & $\begin{array}{c}\text { Area } \\
\text { M2 }\end{array}$ & & $\begin{array}{c}\text { Depth } \\
M\end{array}$ & $\begin{array}{c}\text { Volume } \\
\text { M3 }\end{array}$ & $\begin{array}{c}\text { Category } \\
\text { of Area }\end{array}$ & $\begin{array}{l}\text { Category } \\
\text { of Volume }\end{array}$ \\
\hline 1 & Batur & 15,9 & & 88 & 820 & Small & Medium \\
\hline 2 & Bratan & 3,85 & & 22 & 49 & Small & Small \\
\hline 3 & Buyar & 3,9 & & 87 & 160 & Small & Medium \\
\hline 4 & Diatas & 12,3 & & 44 & Tad & Small & - \\
\hline 5 & Dibawah & 11,2 & & 39 & Tad & Small & - \\
\hline 6 & Kerinci & 46 & & 97 & Tad & Small & - \\
\hline 7 & Limboto & 56 & & 2,5 & Tad & Small & - \\
\hline 8 & Maninjau & 97,9 & & 169 & 10400 & Small & Large \\
\hline 9 & Matano & 164,1 & & 590 & 55015 & Medium & Large \\
\hline 10 & Poso & 323,2 & & 450 & Tad & Medium & - \\
\hline 11 & Ranau & 125,9 & & 229 & Tad & Medium & Large \\
\hline 12 & Rawa Pening & 25 & & 14 & 52 & Small & Small \\
\hline 13 & Sentani & 93,6 & & 42 & Tad & Small & - \\
\hline 14 & Singkarak & 107,8 & & 268 & Tad & Medium & Large \\
\hline 15 & Temblingan & 1,9 & 90 & & 27 & Small & - \\
\hline 16 & Toba & 1130 & & 529 & Tad & Medium & $\begin{array}{l}\text { Very } \\
\text { Large }\end{array}$ \\
\hline 17 & Tempe & 350 & & 5 & Tad & Medium & \\
\hline 18 & Tondano & 50 & & 20 & Tad & Small & \\
\hline 19 & Towuti & 561,1 & & 203 & Tad & Medium & \\
\hline
\end{tabular}

Source: Reservoir/lake Valuation Guide, Ministry of Environment 2020

At normal times, the area of the lake is 47,800 . When it rains continuously, the area of Lake Tempe and the area that is flooded reaches more than 60,000 ha and during the dry season the water shrinks to $3000 \mathrm{Ha}$. The data from the table shows that Lake Tempe (the area of Lake Tempe at normal times) is the third largest lake in Indonesia, after Lake Toba 


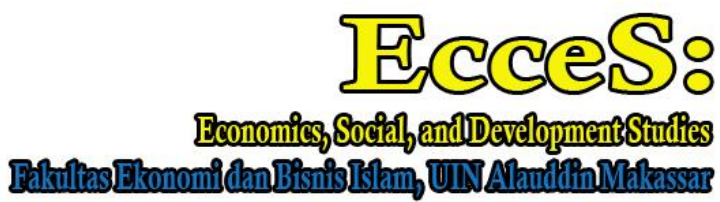

Volume 8 Number 2 Ed. December 2021: page:111-131 p-ISSN: 2407-6635 e-ISSN : 2580-5570

in North Sumatra and Lake Towuti in East Luwu Regency, South Sulawesi. On the other hand, among the existing lakes, Lake Tempe is the shallowest lake in Indonesia with a depth of only 5 meters. Lake Tempe also has problems with ecosystem damage, such as damage to the catchment area due to uncontrolled illegal logging and exacerbated by shifting cultivation so that the critical area of the lake becomes wider from 308,962, $56 \mathrm{Ha}$ to $430,485 \mathrm{Ha}$, resulting in conversion of catchment areas and pockets of water, so that the effect on the catchment area is decreasing and the water reserves that can be stored are getting depleted. Ecological issues have become the focus of stakeholders, along with the worsening of ecological damage, both caused by human social activities and economic activities, this damage is increasingly exacerbating existing ecosystems (Ali et al., 2021; Y. Wang et al., 2021).

In 1998-2002 there was a change in land cover of around 43,632 $\mathrm{Ha}$, there was a decrease in land cover of $5.5 \%$, as a result, a lot of forest around Lake Tempe turned into critical land. The area of critical land in the Lake Tempe ecosystem area is around 170,976 $\mathrm{Ha}$ consisting of 92,187 in the forest area and 78,789 outside the forest area. The damage was caused by illegal logging carried out by the community. Based on the image map of the MIH 2020 program, data on the type of land cover around the lake that is dominant is shrubs around $358.81 \mathrm{Ha}$ or $52 \%$, the next land cover is rice fields $178.73 \mathrm{Ha}$ or about $26 \%$, open land $136.47 \mathrm{Ha}$ and fields or moor about $10.52 \mathrm{Ha}$, and $8.51 \mathrm{Ha}$ mixed garden. The existence of economic activities in the lake area results in pollution that occurs around the lake caused by the disposal of domestic waste, agricultural waste, pesticides, and waste from upstream rivers so that it has an impact on eutrophication that occurs on the surface of the lake water (Bare et al., 2021).

Poor water quality due to decay of organic matter can reduce the amount of dissolved oxygen thereby endangering the life of the bottom of the lake and causing the death of fish and other animals that live in the lake. The existence of community agricultural activities on the shores of the lake causes the reduction of trees, plants and other plants around the edge of the lake. Under normal conditions, these plants become a habitat for aquatic life, besides destroying the perch of birds that usually live on the shores of the lake.

The impact felt by the community due to natural damage in Lake Tempe is the decline in fish catches in Lake Tempe, from year to year. 
Darsam Belana, Economic Valuation of Lake Tempe Area Resources in Wajo Regency; A Socio-Economic and Ecological Approach.

Table 1.2 Types of Fish and Fish Catches in Lake Tempe in 2020

\begin{tabular}{clc}
\hline Num & Varian of fish & $\begin{array}{c}\text { Estimated Catch } \\
\text { (Tons) }\end{array}$ \\
\hline 1 & Tawes (Pantius sp) & 4494,69 \\
\hline 2 & Sepat (Trichogaster tricopterus) & 2375,11 \\
\hline 3 & Mujair (Oreochromismossambicus) & 1715,88 \\
\hline 4 & Gabus (Ophiocephaluspleurothalmus) & 1377,45 \\
\hline 5 & Betok (Anabas tetudineus) & 1257,92 \\
\hline 6 & Mas (Cyprinus carpio) & 786,94 \\
\hline 7 & Nila (Oreochromis niloticus) & 493,59 \\
\hline 8 & Lain-lain (Others) & 71,24 \\
\hline & Total & $12.572,99$ \\
\hline
\end{tabular}

Source : (Ahmad, 2021).

There has been a significant decrease in catches from Lake Tempe from year to year. Lake Tempe was formerly known as the largest water fish producing area in Indonesia. Previously, apart from being a center for freshwater fish production, Lake Tempe was also known as a port for merchant ships in Wajo, besides Lake Tempe as an entity of the political power of the Wajo kingdom and the surrounding kingdoms of Wajo, such as Soppeng, Bone and the "Ajatappareng" areas. . That's why Lake Tempe has a very large historical value and inheritance value in South Sulawesi (Kudsiah et al., 2021).

Seeing the natural damage that has occurred in Lake Tempe, both due to nature and due to human activities in improving their welfare, so that Lake Tempe can still exist and be used by the community to meet their daily needs, there needs to be knowledge about the strategic value of the existence of Lake Tempe. There is a decrease in environmental functions that occur in Lake Tempe, it is interesting to know more about the economic value of the Lake Tempe area, the ignorance of some parties about the economic value of the Lake Tempe area with the Economic Valuation method. so that some policies regarding the Tempe Lake rescue program can be right on target and do not damage the Lake environment (Ahmad, 2021).

The novelty of the research is that it tries to carry out an economic assessment of lake/reservoir damage that can be done based on the value of direct benefits, indirect benefits, value options, and the value of inheritance from the tempe lake ecosystem. Economic valuation is one of the instruments that can be used to calculate the strategic value of the Lake Tempe area in order to increase public and government appreciation and awareness of goods and services produced by natural resources and the environment. Lake/reservoir damage evaluation or economic assessment is the process of identifying, 


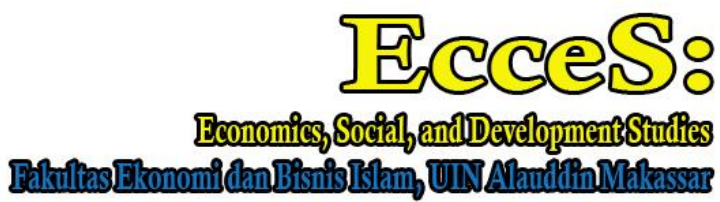

Volume 8 Number 2 Ed. December 2021: page:111-131 p-ISSN: 2407-6635 e-ISSN : 2580-5570

measuring, and determining the economic value of lake damage (Faccioni et al., 2019; Gioglio et al., 2019; Matthew et al., 2019; Najmulmunir et al., 2019; Sundell et al., 2019; Tamsah and Nessa, 2019).

\section{LITERATURE REVIEW}

Ecosystem is an ecological system consisting of biotic and abiotic components that are integrated with each other to form a single unit. In the lake water ecosystem there are abiotic and biotic factors (producers, consumers and decomposers) that form a reciprocal relationship and influence each other. Lake waters are one form of freshwater ecosystems that exist on the earth's surface. Physically, a lake is a large area that has constant, clear or varied water with a certain flow. With all of its potential, the lake becomes the center of the community's social livelihood, to interact with each other (Sven Erik Jorgensen and Vollenweiden, 1989).

However, in contrast to Beutel and Horne (1999) that the lake in its development and the potential contained around it, become the center of community economic activity. They can find fish, develop water tourism and carry out trading activities around the lake. This is supported by the characteristics of the lake, which has a natural body of water that is always flooded throughout the year and has a certain water quality that varies from one lake to another and has high biological productivity. Lake ecosystems include freshwater habitats that have calm waters which are characterized by the presence of very slow currents of about $0.1-1 \mathrm{~cm} / \mathrm{second}$ or no currents at all. Therefore the residence time of water can last longer. Lake waters usually have a vertical stratification of water quality that depends on depth and season.

According to Odum (2003) emphasized that the lake in principle is capable of becoming a center of social and economic activity, this cannot be separated. Given, the history of the lake is not only as an ecological entity, but also as a social and economic entity. For this reason, the potential of the lake can be read on the characteristics and types of the lake itself. Basically the process of the occurrence of lakes can be grouped into two, namely: natural lakes and artificial lakes. Natural lakes are lakes that are formed as a result of natural activities, such as natural disasters, volcanic activities and tectonic activities. Meanwhile, artificial lakes are lakes that are formed intentionally by human activities with certain purposes by making dams in low-lying areas. 
Darsam Belana, Economic Valuation of Lake Tempe Area Resources in Wajo Regency; A Socio-Economic and Ecological Approach.

According to Jorgensen and Vollenweiden (1989) that based on nutrient content (fertility level) lakes are classified into 3 types, namely: eutrophic lakes, oligotrophic lakes and mesotrophic lakes. Eutrophic lakes (high nutrient content) are lakes that have shallow waters, abundant littoral plants, higher plankton density, often algae blooms occur with generally low levels of sunlight penetration. Meanwhile, oligotrophic lakes are lakes with low nutrient content, usually having deep waters, with a larger hypolimnion part than the epilimnion part. The deeper the lake the less fertile, the littoral plants are sparse and the plankton density is low, but the number of species is high. Mesotropic lakes are lakes with moderate nutrient levels, also a transition between the two properties of eutrophic lakes and oligotrophic lakes.

\section{METHODS}

To identify the function and value of the Tempe Lake area, an economic valuation method is used. According to Saleh et al., (2020) economic valuation of natural resources and the environment is an effort to impose a monetary value on part or all of the potential of natural resources and the environment, in accordance with the purpose of their utilization. The economic valuation of natural resources and the environment is used to calculate the total economic value of resources and the environment. This research was carried out in four villages representing four sub-districts in Wajo Regency which are directly adjacent to the Tempe Lake Area or areas where most of the people have an economic dependence on the existence of Tempe Lake, South Sulawesi Province, Indonesia.

The data collected in the form of primary and secondary data. Primary data were obtained through interviews, filling out questionnaires, and direct observations in the field to see firsthand the state of the lake ecosystem, the state of the community, and the activities carried out in the field by the community related to the use of the lake. Interviews were conducted to obtain information and information verbally from respondents in accordance with the questions asked in the questionnaire. Other data needed is data collected to obtain information about commodities that can be sold and cannot be sold, which can describe the productivity of the Lake Tempe area, Wajo district.

Direct Use Value is obtained from the direct use of a resource, which is converted in rupiah, in this case the lake ecosystem, namely benefits such as catching fish, shrimp, secondary crops, and so on, using the following formula:

$$
\text { DUV }=\text { ML1 + ML2 + ML3 +ML4 + ML5... }+ \text { MLn }
$$




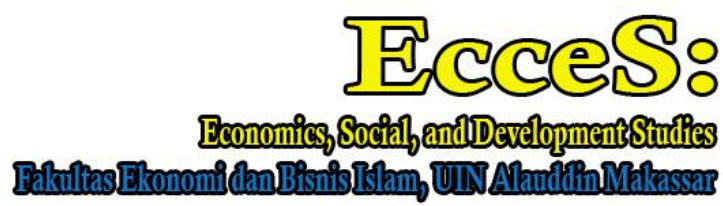

Volume 8 Number 2 Ed. December 2021: page:111-131 p-ISSN: 2407-6635 e-ISSN : 2580-5570

Where $:$ DUV $=$ Direct Use Value, $M L 1=$ Direct Benefits of Fisheries, ML2 $=$ Direct Benefits of Agriculture, ML3 = Direct Benefits of Tourism, ML4 = Direct Benefits of Water Hyacinth, ML5 = Direct Benefits of Clean Water.

The indirect use value of the lake ecosystem can be identified from its physical benefits, namely the provider of resource services that are used indirectly by the community

IUV $=$ MTL1 $+\ldots+$ MLn

Where: IUV = Indirect Use Value MTL1 = Irrigation Use Value, MTLn = nth Indirect Benefit

The total economic value of the utilization of the Tempe Lake area is then calculated by adding up the value of all identified benefits from the ecosystem and quantifying them into values, namely direct benefit value, indirect benefit value, option benefit value, existence benefit value and legacy value from the lake ecosystem. The total economic value can be formulated as follows:

$\mathrm{TEV}=\mathrm{DUV}+\mathrm{IUV}+\mathrm{OV}+\mathrm{EV}+\mathrm{BV}$

Where $: \mathrm{TEV}=$ Total Economic Value, $\mathrm{DUV}=$ Direct Use Value, IUV= Indirect Use Value, $\mathrm{OV}=$ Preferred Value, $\mathrm{EV}=$ Existence Value, $\mathrm{BV}=$ Inheritance Value

\section{RESULT AND DISCUSSION}

\section{Tourism Direct Benefits}

The number of foreign tourists in 2014 was 2800 people. So the total expenditure of Rp. 4,453,400,000,000 and the total expenditure for domestic tourists is Rp. $144,900,000$. The direct value of tourism in Lake Tempe is the accumulated travel costs incurred to enjoy the natural beauty that exists in Lake Tempe.

Table 1.3 Comparison of Total Expenditures for Domestic and International Tourists in 2020

\begin{tabular}{lr}
\hline Type of Tourist & Value (Ruphias) \\
\hline Foreign Tourist & 4.453 .400 .000 .000 \\
\hline Domestic Tourist & 144.900 .000 \\
\hline Total & 4.453 .544 .900 .000
\end{tabular}

Source: Primary data output after processing, 2020; (Darsam, 2020)

The total direct agricultural benefit in Lake Tempe, Wajo Regency, is the accumulation of direct benefits from the use of tidal areas in the four sub-districts 
Darsam Belana, Economic Valuation of Lake Tempe Area Resources in Wajo Regency; A Socio-Economic and Ecological Approach.

in Wajo Regency. So the direct value of tourism in Lake Tempe is Rp. $4,453,544,900,000$. The direct benefits of this lake seem to have contributed greatly to tourism. This finding is in line with previous research which revealed that lakes are not only a source of social livelihood, but also a medium of income for local residents (Beutel and Horne, 1999; Sven Erik Jorgensen and Vollenweiden, 1989; Kudsiah et al., 2021).

\section{Direct Benefits of Water Hyacinth}

From the accumulated benefits of water hyacinth from the value of biogas, the value of liquid fertilizer as a substitute for urea fertilizer, the value of increasing agricultural production, and the marketed value of liquid fertilizer, the total direct benefit of water hyacinth / year is Rp. 335,616,000. This finding is in line with previous research which revealed that water hyacinth is considered a non-value commodity in various places.

Table 1.4 Value of Water Hyacinth in Lake Tempe, Wajo Regency in 2020

\begin{tabular}{lr}
\hline Nilai Ekonomi Eceng Gondok & Jumlah (Rp) \\
\hline Nilai Biogas & 816.000 \\
\hline Nilai Pupuk Cair Sebagai pengganti Pupuk Urea & 64.800 .00 \\
\hline Nilai Pupuk cair untuk dipasarkan & 270.000 .000 \\
\hline Total Nilai Eceng Gondok & 335.616 .000
\end{tabular}

Source: Primary data output after processing, 2020; (Darsam, 2020)

In fact, in developing countries it is considered a nuisance plant, so it is not given much attention. However, in certain areas. This can be one of the leading commodities, if it is processed properly (Albright, 2004; Bare et al., 2021; S E Jorgensen and Vollenweiden, 1989). Pada level yang lebih tinggi, eceng gondok dapat ditransformasi menjadi komoditas untuk industri kreatif (Li, 2020; Wang and Zhang, n.d.).

\section{Direct Benefits of Drinking Water}

The direct benefit of drinking water is calculated by the amount of raw water used by PDAM Wajo Regency. The raw water is taken from the Cenrana river which is the outlet of Lake Tempe. The amount of raw production from the Cenrana river during 2014 was $3,285,026.84$ while the distributed water was $2,544,431.14$. The price per for the Wajo Regency area is Rp. 2500,. The amount of water distributed X Unit Price of clean water per 


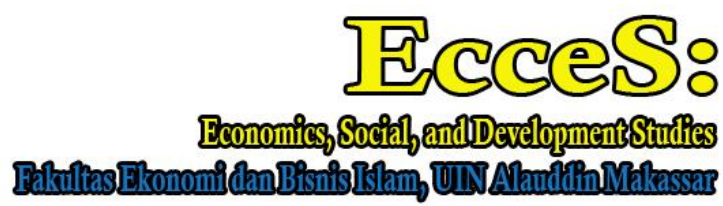

Volume 8 Number 2 Ed. December 2021: page:111-131 p-ISSN: 2407-6635 e-ISSN : 2580-5570

$2,544,431.14 \times 2,500$ Rupiah $=6,361,077,850$. Rupiah. So the direct benefits of clean water in Lake Tempe in 2014 amounted to 6,361,077,850 Rupiah. Lake water resources have tremendous potential.

Table 1.5 Direct Benefits of Clean Water by PDAM Sengkang City in 2020

\begin{tabular}{lr}
\hline Item & Total \\
\hline Amount of water distributed & $2.544 .431,14$ \\
\hline Clean water unit price per ${ }^{\mathrm{m} 3}$ & 2.500 Rupiah \\
\hline Direct Benefits of Clean Water & 6.361 .077 .850 \\
\hline
\end{tabular}

Source: Primary data output after processing, 2020; (Darsam, 2020)

This finding is in line with previous research which revealed that if the lake's potential is managed properly, it can bring in large income for the government, one of which is being a provider of drinking water sources for the wider community. For this reason, the sustainability of drinking water sources for many people is quite dependent on the lake's water resources (Abd Ellah, 2020; Alamanos et al., 2019; Dong et al., 2020; Hou et al., 2020; Liu et al., 2021, 2020; J. Wang et al., 2021; Wang et al., 2019).

\section{Direct Agricultural Benefits}

The total value of the use of tidal areas as agricultural land in four sub-districts is $46,078,200,000$ Rupiah. This indicates that agricultural commodities can not only be produced from land agriculture. However, agriculture around the lake holds great potential for the people around the lake.

Table 1.6 Total Direct Benefits of Agriculture in Tidal Areas

Tempe Lake 2020

\begin{tabular}{lr}
\hline Tidal Area & Agricultural Direct Value (Rp) \\
\hline Belawa & 20.760 .000 .000 \\
\hline Tanasitolo & 5.166 .800 .000 \\
\hline Tempe & 2.064 .600 .000 \\
\hline Sabbamparu & 18.086 .800 .000 \\
\hline Total & $46,078,200,000$
\end{tabular}

Source: Primary data output after processing, 2020; (Darsam, 2020)

This is in line with previous findings that the ecological balance of the lake can be a trigger for the fertility of the land around the lake so that it can provide direct benefits for agricultural activities, which are able to support the surrounding community (Alaye et al., 
Darsam Belana, Economic Valuation of Lake Tempe Area Resources in Wajo Regency; A Socio-Economic and Ecological Approach.

2020; Barros et al., 2020; Jindo et al., 2020; Murphy, 2020; Ngondjeb and Ayuk, 2021; Panagopoulos and Dimitriou, 2020; Polontoh et al., 2019; Zamparas et al., 2020; Zheng et al., 2020).

\section{Direct Benefits of Fisheries}

Fishermen who sell their catch wet, there are selling per basin containing all types of fish caught, usually in a fish basin at an estimated price of 50,000 to 75,000 Rupiah. Fishermen who sell per basin are usually from Pajalele Village, Pakkanna Village and Assorajang Village, Tanasitolo District. Non-fish lake products are also available, for example Baje' (a type of small shellfish) for 15,000 Rupiah per liter and Cuco (a type of rice field snail) is usually sold at Rp. the price is 10,000 Rupiah per liter.

The average income of fishermen once down to the lake is 107,350 Rupiah, in a week 644,100 Rupiah, in a year 34,781,400 Rupiah. The number of fishermen in Lake Tempe is 1871 . The total direct benefit of fisheries is Rp. $65,075,999,400$. It seems that the potential of fishery resources around the lake shows direct benefits that are quite high in value for the community. This is in line with previous findings that in various places there is a very large potential in terms of fishery resources around the lake.

Table 1.7 Total Direct Benefits of Fisheries in Lake Tempe, Wajo Regency in 2020

Average daily income of fishermen

$\operatorname{Rp} 107.350$

Number of RTP (Fishing Household) $1871 \mathrm{KK}$

Direct Benefits of Fisheries Rp. 65.075.999.400

Source: Primary data output after processing, 2020; (Darsam, 2020)

Historically, until thousands of years ago, lakes have become the hope of people's livelihoods, in terms of fulfilling animal protein. Mainly, for fishery commodities. People's dependence on this is getting higher from time to time (Alaye et al., 2020; Barros et al., 2020; Jindo et al., 2020; Murphy, 2020; Ngondjeb and Ayuk, 2021; Panagopoulos and Dimitriou, 2020; Polontoh et al., 2019; Zamparas et al., 2020; Zheng et al., 2020).

\section{Total direct benefit of Tempe Lake}

The total direct benefits of the existence of Lake Tempe in Wajo Regency are the accumulation of direct agricultural benefits, direct benefits of fisheries, direct benefits of tourism, and direct benefits of water hyacinth. So the direct benefit of the Lake Tempe area, Wajo district, is Rp. 571,395.793,250. The potential of resources in the lake, seems very large. Of course, this is reflected in the direct benefits provided. 


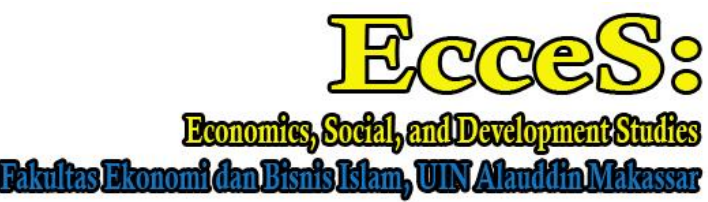

Volume 8 Number 2 Ed. December 2021: page:111-131 p-ISSN: 2407-6635 e-ISSN : 2580-5570

Table 1.8 Total Direct Benefits of Tempe Lake in 2020

Direct Benefit Type Total (Rp)

Direct Agricultural Benefits

46.078.200.000

Direct Benefits of Fisheries 65.075 .999 .400

Tourism Direct Benefits

4.453.544.900.000

Direct Benefits of Water Hyacinth 335.616 .000

Direct Benefits of Clean Water 6.361 .077 .850

Total Immediate Benefit

4.571.395.793.250

Source: Primary data output after processing, 2020; (Darsam, 2020)

This is in line with the findings of previous studies that the various potentials contained in the lake are not only limited to social potential. However, it also has a direct economic impact on the surrounding community, both from the fisheries sector, agriculture, creative micro-enterprises and various other potentials (Bockarjova et al., 2020; Faccioni et al., 2019; Johnson et al., 2021; Kirk, 2019; Maher et al., 2021; Matthew et al., 2019; Pakalniete et al., 2021; Pisani et al., 2021; Saleh et al., 2020; Sena et al., 2020).

\section{Total Indirect Benefits}

Table 1.9 Total Indirect Benefits of Regional Areas

Tempe Lake 2020

\begin{tabular}{lr}
\hline Description & \multicolumn{1}{c}{ Jumlah (Rp) } \\
\hline Indirect benefits of irrigation & 178.427 .640 .000 \\
\hline Indirect benefits of cultural rituals & 145.000 .000 \\
\hline Indirect benefits of sports facilities & 12.000 .000 \\
\hline Total indirect benefits of Lake Tempe, Wajo Regency & 178.584 .640 .000
\end{tabular}

Source: Primary data output after processing, 2020; (Darsam, 2020)

The total indirect benefits are obtained from the accumulation of direct benefits of irrigation, indirect benefits of cultural rituals, and indirect benefits of sports facilities. The total indirect benefits of the Tempe Lake area, Wajo Regency, amounted to Rp. $178,584,640,000$. 
Darsam Belana, Economic Valuation of Lake Tempe Area Resources in Wajo Regency; A Socio-Economic and Ecological Approach.

\section{Benefits of Existence}

Existence benefits are values that are measured by the benefits felt by the community because of the existence of Lake Tempe, Wajo Regency. This value is obtained by using a qualitative analysis of the responses regarding WTA respondents who work as fishermen and farmers. WTA is used to see how much value the existence of Lake Tempe has in supporting their lives. The steps in determining the WTA are to form a hypothetical market, get a quote for the amount of WTA, estimate the estimated average WTA, and add up the data.

Table 1.10 Total Existence Value of Lake Tempe Area, Wajo Regency in 2020

\begin{tabular}{lr}
\hline \multicolumn{1}{c}{ Description } & Total \\
\hline Number of Respondents & 100 orang \\
\hline Average WTA/Month & $32.440 .822 .200 .000,-$ \\
\hline Average number of WTA/Year & 1871 orang \\
\hline The number of people who depend on Lake Tempe & $6120 \mathrm{Ha}$ \\
District Wajo & \\
\hline The area of Lake Tempe at Normal time / Ha (51\% & \\
of the total area of the lake Tempe normal time of & \\
12,000 Ha) & $60.404 .810 .936 .400 .000,-$ \\
\hline The total value of the benefits of the existence of \\
Lake Tempe for a year
\end{tabular}

Source: Primary data output after processing, 2020; (Darsam, 2020)

To ask the amount of Willingness To Accept (WTA) for each respondent, the researcher uses the Open Ended method. The Open Ended Method is one of the methods in the evaluation format of the CVM method to measure the amount of WTA by not limiting respondents to the choices of WTA quantities prepared in the interview process. The Open Ended method provides an opportunity for respondents to determine the amount of WTP for themselves according to what the respondent experiences. Based on the results of interviews in the field, the highest WTA value is Rp. $2,700,000,000,000,000,-$ and the lowest WTA is Rp. 100,000. The average number of WTA is Rp. $27,034,018,500,-$ per month and the number of WTA in a year is Rp. $32,440,822,200,000$. 


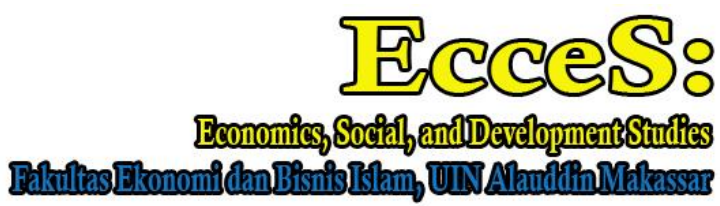

Volume 8 Number 2 Ed. December 2021: page:111-131 p-ISSN: 2407-6635 e-ISSN : 2580-5570

\section{Inheritance Benefits}

The inheritance benefit is calculated from the value using the Contingent Valuation Method (CVM), by calculating the Value of Willingness To Pay (WTP) obtained so far.

To ask the amount of Willingness To Pay (WTP) for each respondent, the researcher uses the Open Ended method. The Open Ended Method is one of the methods in the evaluation format of the CVM method to measure the amount of WTP by not limiting respondents to the choices of WTP quantities prepared in the interview process. The Open Ended method provides an opportunity for respondents to determine the amount of WTP for themselves according to what the respondent experiences.

Table 1.11 Total Value of WTP Inheritance Value in 2020

\begin{tabular}{lr}
\hline Description & Total \\
\hline Lowest WTP Value & Rp. 500.000,- \\
\hline Highest WTP Value & Rp. 115.850,- \\
\hline Average WTP & 1871 orang \\
\hline Number of Lake Beneficiaries & Rp. 216.755.350,- \\
\hline Total WTP From Lake Tempe/Month & Rp. 2.601.064.200,- \\
\hline Total WTP/Year
\end{tabular}

Source: Primary data output after processing, 2020; (Darsam, 2020)

The WTP value is calculated based on the perceived value of environmental service users on the sustainability of the Tempe Lake ecosystem so that it can be enjoyed by next generations. In determining the value of WTP, respondents are not limited and are not given certain choices in determining the nominal value to be paid. Based on the results of the field survey, there is a mandatory fee (retribution) set by the Maritime Affairs and Fisheries Service for fishermen in Lake Tempe, Wajo Regency, amounting to Rp, 35.000,--, so that this becomes the basis for the nominal figure to determine the nominal amount of WTP that will be offered to respondents.

Based on the results of the interview, the lowest value of WTP is 0 and the highest number of WTP is Rp. 500,000 Rupiah with a total WTP of all respondents of Rp. 11.585.000,-. The average value of WTP is Rp. 115,850, - and the number of direct beneficiaries of the existence of Lake Tempe which is calculated from the 
Darsam Belana, Economic Valuation of Lake Tempe Area Resources in Wajo Regency; A Socio-Economic and Ecological Approach.

number of fishermen and farmers is 1871 people. So the inheritance value of Lake Tempe based on the Contingent Valuation Method is Rp. 2,601,064,200.

\section{Choice Benefits}

The value of the option is calculated using the Contingent Valuation Method (CVM). CVM is calculated based on the ability to pay for environmental services to beneficiaries. To ask the amount of Willingness To Pay (WTP) for each respondent, the researcher uses the Open Ended method. The Open Ended Method is one of the methods in the evaluation format of the CVM method to measure the amount of WTP by not limiting respondents to the choices of WTP quantities prepared in the interview process. The Open Ended method provides an opportunity for respondents to determine the amount of WTP for themselves according to what the respondent experiences.

Based on the results of interviews, the total ability to pay for environmental services by recipients of environmental services in the Lake Tempe area, Wajo Regency is Rp. 2,601,064,200.

\section{Total Economic Value of Tempe Lake Area, Wajo Regency}

The Total Economic Value (NET) for the Lake Tempe area, Wajo Regency based on the sum of all direct benefits, indirect benefits, inheritance benefits, existence benefits, and choice benefits, the total economic value is obtained on the table. The Total Economic Value (NET) of the Tempe Lake area of Wajo Regency is Rp. 5,742,249,708,120.

Table 1.12 Total Economic Value of Tempe Lake Area, Wajo Regency

Benefit Type Benefit Value (Rp/year) Precentage

(\%)

\begin{tabular}{lrr}
\hline Immediate Benefits & 4.571 .395 .793 .250 & 78,7 \\
\hline Indirect Benefits & 178.584 .640 .000 & 4,1 \\
\hline Benefits of Existence & 987.067 .146 .470 & 17 \\
\hline Choice Benefits & 2.601 .064 .200 & 0,04 \\
\hline Inheritance Benefits & 2.601 .064 .200 & 0,04 \\
\hline Total Economic Value & 5.742 .249 .708 .120 & 100
\end{tabular}

Source: Primary data output after processing, 2020; (Darsam, 2020).

Based on the table above, the value of direct benefits has the largest percentage, which is 78.8 percent. The direct value of the benefits is felt by the fisheries, agriculture and tourism sectors so that the direct benefits have greater 


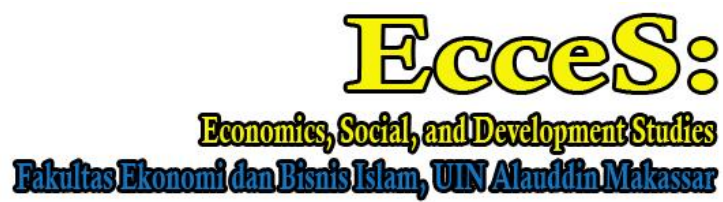

Volume 8 Number 2 Ed. December 2021: page:111-131 p-ISSN: 2407-6635 e-ISSN : 2580-5570

benefits. The benefit of the existence of Lake Tempe is 17 percent, calculated using the WTA so that the value is very large. The indirect benefits of Lake Tempe are 4.1 percent and the choice benefits and inheritance benefits are 0.04 percent.

\section{Negative Externalities}

Another problem faced by the people of Lake Tempe is the issue of ownership rights. For the people of Lake Tempe, the lake is considered a public property whose use is used for the common good. All residents of Lake Tempe have the same opportunity to manage and utilize Lake Tempe to support their daily lives.

However, this condition is faced with the problem of conflict of interest when all economic actors in the area seek to maximize profits. When all fishermen try to maximize profits by using existing resources, be it available human labor, capital, fishing equipment (technological levels) are different, of course, the control of the lake is determined by how much power the resources have.

In this reality, conflicts of interest often occur when fishing around Lake Tempe. There are some fishermen who set up a large enough fish cage (bungka toddo) so that other fishermen according to customary law are not allowed to catch fish in that area because other fishermen have already claimed the area as a fishing area. In this condition, the maximization of the personal profit of some fishermen who have strong capital causes dominance of the catch and causes the catch of other fishermen to decrease.

\section{Imperfection Public goods}

In economic activities controlled by market mechanisms, of course, it will not be optimal if it is not supported by the provision of public goods such as roads, bridges, and fish landing sites. For the people of Lake Tempe, the lack of provision of public goods for the people of Lake Tempe in supporting economic activities is a classic problem that has not been resolved until now. The bridge that connects the upstream economic activity center of the Lake Tempe community in the four sub-districts with the downstream economic activity center in Wajo Regency is very minimal and limited. As a result, the results of fisheries and agricultural activities produced by the Lake Tempe Community in the Wette'e area in Lautang Village are mostly marketed in the Sidrap area because the distance is closer and also the infrastructure in Wajo Regency is not adequate. 
Darsam Belana, Economic Valuation of Lake Tempe Area Resources in Wajo Regency; A Socio-Economic and Ecological Approach.

\section{Vertical Conflict}

Vertical conflict between bungka toddo' cage fishermen and the government. The construction of a mobile dam to maintain the stability of the water level in Lake Tempe is detrimental to the bungka toddo' cage fishermen who rely on fluctuations in the lake water level. So that on June 6, a demonstration was held at the Wajo district DPRD office, they demanded that the motion dam not be optimized for its function. The ex-ornament area they got through a closed auction and the very expensive cost of making cages made the bungka toddo' fisherman lose because no fish were trapped due to the stable condition of the lake water level.

On the other hand, with stable water conditions, ordinary fishermen "pakkaja lelle" feel very useful because fish can roam in areas that are not ex-ornament areas controlled by bungka toddo fishermen. The conflict between ordinary fishermen and the government was due to regulations regarding the prohibition of some fishing gear, so that several groups of fishermen held demonstrations at the Wajo Regency DPRD office. The prohibited fishing gear are tiger trawls, iron traps (jabba bessi), and trawls with a net width of less than $2 \mathrm{~cm}$. According to them, the reason fishermen use the fishing gear is because the physical condition of the fish is getting smaller day by day, so that if the net is $2 \mathrm{~cm}$. used they can't get fish. The reason fishermen use tiger trawlers is because to get shrimp that has mud at the bottom of the lake, but usually there are also small fish that come in, so when it's getting late they don't have time to sort the small fish and are left to die.

\section{CONCLUSION}

Based on the results of the Economic and Resource Valuation research in the Lake Tempe area, Wajo Regency that has been carried out, it can be concluded: 1). Lake Tempe has provided direct benefits including, (a) the benefits of catching fishery products and nonfish fishery products as commodities for fishing communities, (b) direct benefits of tourism which have the potential to be developed further and can increase local revenue in the form of hotel taxes and restaurants and fees for entering the Tempe Lake area for tourists, (c) Direct benefits of water hyacinth plants as alternative energy and as basic ingredients for making organic fertilizers, (d) utilization of the lake as a source of clean water for the community. Regarding the indirect benefits, it is found that there are tourism benefits and irrigation benefits in this study. 2). The total economic value of the Tempe Lake area in Wajo Regency is Rp. $5,742,249,708,120$. This value is obtained from the accumulated value 


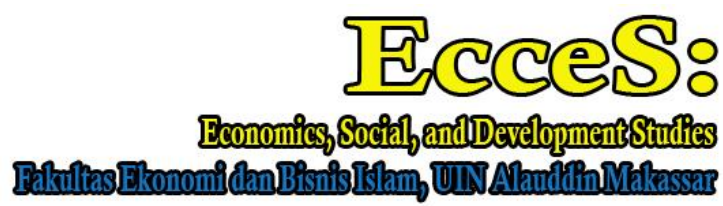

Volume 8 Number 2 Ed. December 2021: page:111-131 p-ISSN: 2407-6635 e-ISSN : 2580-5570

of direct benefits of $178,584,640,000(78.7 \%)$, the value of indirect benefits of $\mathrm{Rp}$. $238,364,640,000$ (4.1\%), the value of the existence benefit is Rp. $987,067,146,470(17 \%)$, the value of the inheritance benefits is Rp. 2,601,064,200 (0.04\%) and the value of the option benefit is $2,601,064,200(0.04 \%)$.

The implications of this research include; 1 ). With the siltation due to sedimentation, it is necessary to have cross-sectoral coordination from various levels of government, to encourage the rehabilitation of forest areas around the Walennae and Bila watersheds. Dredging of Lake Tempe is urgently needed to overcome the annual flooding due to overflowing lake water, 2). With the use of Lake Tempe which is very large, and several other potentials of Lake Tempe that have not been utilized, such as the utilization of the sedimentary mud of Lake Tempe, the use of shrubs in the lake area as medicine. So, in order to improve the utilization of Lake Tempe, it is necessary to involve academics, researchers, NGOs, the government, and any other party to see the other untapped potential of the Lake Tempe area.

\section{REFERENCES}

Abd Ellah, R.G., 2020. Water resources in Egypt and their challenges, Lake Nasser case study. Egypt. J. Aquat. Res. 46, 1-12.

Ahmad, A., 2021. Kompleksitas Sistem Pemanfaatan Wilayah Tangkapan Dan Lahan Garapan Di Danau Tempe. Tarjih Agribus. Dev. J. 1, 26-31.

Alamanos, A., Latinopoulos, D., Papaioannou, G., Mylopoulos, N., 2019. Integrated hydroeconomic modeling for sustainable water resources management in data-scarce areas: The case of lake Karla watershed in Greece. Water Resour. Manag. 33, 2775-2790.

Alaye, S.A., Adeagbo, A.A., Meduna, P.N., Joshua, D.A., Ojo, B.S., 2020. Wildlife conservation and agrarian economy in communities around Kainji Lake National Park, Niger State, Nigeria. J. Res. For. Wildl. Environ. 12, 138-144.

Albright, T., 2004. The rise and fall of water hyacinth in Lake Victoria and the Kagera River Basin, 1989-2001.

Ali, A., Yazdani, M., Ghanbari, S., Akbarzadeh, H., Jafari, A., Farrokh, H., 2021. Arti fi cial neural network model to predict the compressive strength of eco-friendly geopolymer concrete incorporating silica fume and natural zeolite 279. 
Darsam Belana, Economic Valuation of Lake Tempe Area Resources in Wajo Regency; A Socio-Economic and Ecological Approach.

Bare, R.R., Mukmin, A., Kesuma, A.I., Akib, H., Pattarani, A., 2021. Reframing the Village Fund Program in Revitalizing Tempe Lake as a Tourist Destination. Turkish Online J. Qual. Inq. 12, 245-256.

Barros, M.V., Salvador, R., de Francisco, A.C., Piekarski, C.M., 2020. Mapping of research lines on circular economy practices in agriculture: From waste to energy. Renew. Sustain. Energy Rev. 131, 109958.

Beutel, M.W., Horne, A.J., 1999. A review of the effects of hypolimnetic oxygenation on lake and reservoir water quality. Lake Reserv. Manag. 15, 285-297.

Bockarjova, M., Botzen, W.J.W., Koetse, M.J., 2020. Economic valuation of green and blue nature in cities: A meta-analysis. Ecol. Econ. 169, 106480.

Dong, N., Yang, M., Yu, Z., Wei, J., Yang, C., Yang, Q., Liu, X., Lei, X., Wang, H., Kunstmann, $H_{.}$, 2020. Water resources management in a reservoir-regulated basin: Implications of reservoir network layout on streamflow and hydrologic alteration. J. Hydrol. 586, 124903.

Faccioni, G., Sturaro, E., Ramanzin, M., Bernués, A., 2019. Socio-economic valuation of abandonment and intensification of Alpine agroecosystems and associated ecosystem services. Land use policy $81,453-462$.

Gioglio, R., Sohngen, B., Haab, T., Bruskotter, J., 2019. Economic valuation of natural areas in Ohio. Coll. food, Agric. Environ. Sci. Ohio State Univ. 1-30.

Hou, X., Wang, X., Chen, L., Zhu, S., Wang, J., Sun, X., Diao, Y., 2020. Evaluation on sustainable utilization of water resources in Nansi Lake Basin. In: IOP Conference Series: Earth and Environmental Science. IOP Publishing, p. 12077.

Jindo, K., Audette, Y., Higashikawa, F.S., Silva, C.A., Akashi, K., Mastrolonardo, G., SánchezMonedero, M.A., Mondini, C., 2020. Role of biochar in promoting circular economy in the agriculture sector. Part 1: A review of the biochar roles in soil N, P and $\mathrm{K}$ cycles. Chem. Biol. Technol. Agric. 7, 1-12.

Johnson, D., Exl, J., Geisendorf, S., 2021. The Potential of Stormwater Management in Addressing the Urban Heat Island Effect: An Economic Valuation. Sustainability 13, 8685.

Jorgensen, Sven Erik, Vollenweiden, R.A., 1989. Guidelines of lake management, Principles of lake management. Int. lake Environ. Comm. Fed. Otsu 199.

Jorgensen, S E, Vollenweiden, R.A., 1989. Guedelines of Lakes Management: Principles of Lakes Management Vol 1. International Lake Environment Foundation. Shiga-Japan. 


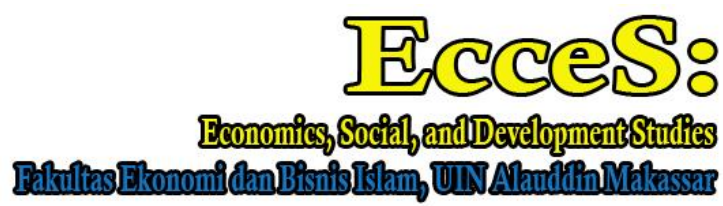

Volume 8 Number 2 Ed. December 2021: page:111-131 p-ISSN: 2407-6635 e-ISSN : 2580-5570

Jorgensen, SE 1989. Use of model. Guedelines Lakes Manag. 1, 71-89.

Kirk, C.P., 2019. Dogs have masters, cats have staff: Consumers' psychological ownership and their economic valuation of pets. J. Bus. Res. 99, 306-318.

Kudsiah, H., Rahim, S.W., Hidayani, A.A., Moka, W., 2021. Population dynamic of bungo fish (Glossogobius giuris) in three integrated lakes (Danau Tempe, Danau Sidenreng, and Danau Lampokka) South Sulawesi during rainy season. In: IOP Conference Series: Earth and Environmental Science. IOP Publishing, p. 12010.

Li, X., 2020. Cultural creative economy and urban competitiveness : How one matters to the other. J. Urban Aff. 00, 1-16.

Liu, B., Wang, Y., Xia, J., Quan, J., Wang, J., 2021. Optimal water resources operation for rivers-connected lake under uncertainty. J. Hydrol. 595, 125863.

Liu, Y., Yang, L., Jiang, W., 2020. Coupling coordination and spatiotemporal dynamic evolution between social economy and water environmental quality-A case study from Nansi Lake catchment, China. Ecol. Indic. 119, 106870.

Maher, A.T., Quintana Ashwell, N.E., Maczko, K.A., Taylor, D.T., Tanaka, J.A., Reeves, M.C., 2021. Valuation of beef cattle ecosystem services An economic valuation of federal and private grazing lands ecosystem services supported by beef cattle ranching in the US. Transl. Anim. Sci.

Matthew, N.K., Shuib, A., Ramachandran, S., Mohammad-Afandi, S.H., 2019. Economic valuation using travel cost method (TCM) in kilim karst geoforest park, Langkawi, Malaysia. J. Trop. For. Sci. 31, 78-89.

Murphy, M.K., 2020. "We Are Seneca Lake": Defining the Substances of Sustainable and Extractive Economics Through Anti-Fracking Activism. Front. Commun. 5, 27.

Najmulmunir, N., Kamilah, A., Amaliah, S., 2019. Economic Valuation of Rice Paddy

Biomass: Case Study at Village of Sukakarya, Regency of Bekasi.

Ngondjeb, D.Y., Ayuk, E., 2021. Economic valuation of environmental services associated with agriculture in the watershed of lake Lagdo, Cameroon. In: A Nexus Approach for Sustainable Development. Springer, pp. 93-105.

Odum, H.T., Odum, B., 2003. Concepts and methods of ecological engineering. Ecol. Eng. 20, 339-361.

Pakalniete, K., Ahtiainen, H., Aigars, J., Andersone, I., Armoškaite, A., Hansen, H.S., Strāḳe, S., 2021. Economic Valuation of Ecosystem Service Benefits and Welfare Impacts of 
Darsam Belana, Economic Valuation of Lake Tempe Area Resources in Wajo Regency; A Socio-Economic and Ecological Approach.

Offshore Marine Protected Areas: A Study from the Baltic Sea. Sustainability 13, 10121. Panagopoulos, Y., Dimitriou, E., 2020. A large-scale nature-based solution in agriculture for sustainable water management: The Lake Karla case. Sustainability 12, 6761.

Pisani, D., Pazienza, P., Perrino, E.V., Caporale, D., De Lucia, C., 2021. The Economic Valuation of Ecosystem Services of Biodiversity Components in Protected Areas: A Review for a Framework of Analysis for the Gargano National Park. Sustainability 13, 11726.

Polontoh, H.M., Katjong, K., Yanuaria, T., 2019. Investment Application Model in the Sentani Lake Management to Improve the Community Economy of Customary Rights Holders. JL Pol'y Glob. 90, 138.

Saleh, I., Khosravy, M., Sadeghi Boshrabadi, A., Rafiee, H., Shahnabati, N., Saleh, H.R., 2020. Economic Valuation of Ecosystem Conservation Using Dichotomous Choice Approach (Case Study: Khabar National Park). J. Agric. Sci. Technol. 22, 1165-1175. Sena, M., Morris, M.R., Seib, M., Hicks, A., 2020. An exploration of economic valuation of phosphorus in the environment and its implications in decision making for resource recovery. Water Res. 172, 115449.

Sundell, J., Norberg, T., Haaf, E., Rosén, L., 2019. Economic valuation of hydrogeological information when managing groundwater drawdown. Hydrogeol. J. 27, 1111-1130.

Tamsah, H., Nessa, N., 2019. The application of economic-valuation in the calculation of damage to coral reefs ecosystems in Indonesia. In: IOP Conference Series: Earth and Environmental Science. IOP Publishing, p. 12096.

Wang, J., Mu, X., Chen, S., Liu, W., Wang, Z., Dong, Z., 2021. Dynamic evaluation of water resources carrying capacity of the Dianchi Lake Basin in 2005-2015, based on DSPERM framework model and simulated annealing-projection pursuit model. Reg. Sustain. 2, 189-201.

Wang, S., Zhang, B., n.d. WATERING DOWN ENVIRONMENTAL REGULATION IN CHINA* Guojun He Shaoda Wang † Bing Zhang.

Wang, X., Dong, Z., Xu, W., Luo, Y., Zhou, T., Wang, W., 2019. Study on spatial and temporal distribution characteristics of coordinated development degree among regional water resources, social economy, and ecological environment systems. Int. J. Environ. Res. Public Health 16, 4213.

Wang, Y., Hu, H., Dai, W., Burns, K., 2021. Evaluation of industrial green development and industrial green competitiveness : Evidence from Chinese urban agglomerations 124. 


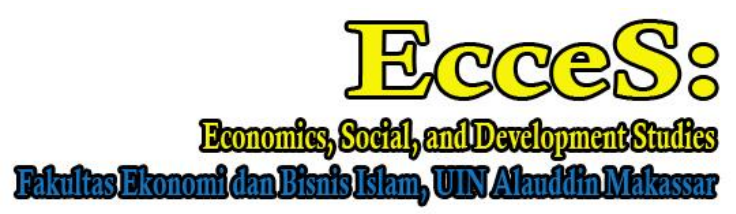

Volume 8 Number 2 Ed. December 2021: page:111-131 p-ISSN: 2407-6635 e-ISSN : 2580-5570

Zamparas, M., Kyriakopoulos, G.L., Drosos, M., Kapsalis, V.C., Kalavrouziotis, I.K., 2020.

Novel composite materials for lake restoration: a new approach impacting on ecology and circular economy. Sustainability 12, 3397.

Zheng, L., Liu, H., An, Z., Chen, X., 2020. Changes in the intensity of human activities in the Erhai Lake Basin and its impact on the lake water environment. 